\title{
Evaluation of BSPcast Disease Warning System in Reduced Fungicide Use Programs for Management of Brown Spot of Pear
}

\author{
I. Llorente, Associate Professor, Institute of Food and Agricultural Technology-CeRTA, University of Girona, \\ 17071 Girona (Spain); P. Vilardell, Research Agronomist, Mas Badia Agricultural Experiment Station, La Tallada, \\ Girona (Spain); R. Bugiani, Research Agronomist, Servizio Fitosanitario-Regione Emilia-Romagna, Via di Corti- \\ cella 133, Bologna (Italy); I. Gherardi, Associate Professor, Dipartimento de Produzione e Valorizacione Agraria, \\ University Degli Studi di Bologna, Via Filippo Re 8, 40126 Bologna (Italy); and E. Montesinos, Professor, Institute \\ of Food and Agricultural Technology-CeRTA, University of Girona, 17071 Girona (Spain)
}

\begin{abstract}
Llorente, I., Vilardell, P., Bugiani, R., Gherardi, I., and Montesinos, E. 2000. Evaluation of BSPcast disease warning system in reduced fungicide use programs for management of brown spot of pear. Plant Dis. 84:631-637.

A forecasting model (BSPcast) developed for prediction of brown spot (Stemphylium vesicarium) of pear was evaluated as an advisory system for reduced fungicide use in disease management programs. Eleven trials were performed during 1995, 1996, and 1997 in five orchards in two different climatic areas in Catalunya (Spain) and Emilia-Romagna (Italy). Values of 3-day cumulative daily infection risk $(\mathrm{CR})$ provided by the model were used to determine risk periods during the growing season of pear and were taken as thresholds to schedule fungicide sprays. The fungicide application programs tested using the model consisted of guided schedules with CR action thresholds of $0.4,0.5$, or 0.6 , and fixed sprays following a standard commercial schedule. In nine out of 10 trials, no significant differences were observed in disease incidence on fruit at harvest between the fixed-spray commercial schedule and guided sprays using thresholds of 0.4 or 0.5 . The average savings in number of fungicide sprays applied using BSPcast compared with the fixed-spray schedule were 20 to $70 \%$ when using fungicides with a 15-day protection period (kresoxim-methyl or procymidone) and ranged from 20 to $50 \%$ when using a fungicide with a 7-day protection period (thiram).
\end{abstract}

Brown spot is an economically important fungal disease of pear, caused by Stemphylium vesicarium (Wallr.) E. Simmons (teleomorph Pleospora allii (Rabenh.) Ces. \& De Not.), which affects several pear growing areas of Europe, including Catalunya in Spain (36), Emilia-Romagna in Italy (31), and Bouches du Rhône in France (2). Necrosis occurs on leaves, fruit, and twigs as a result of infections and production of a host-specific toxin (8). Host susceptibility differs, and the most susceptible pear cultivars are Abate Fetel, Passe Crassane, Alexandrine, and Conference $(2,9,25)$.

Control of brown spot of pear is currently achieved with preventative sprays of carbamate fungicides (e.g., thiram) applied at 7-day intervals or with carboximides (e.g., procymidone) sprayed at 15-day intervals $(3,31,36)$. The commercial schedule for disease management consists of starting fungicide sprays after petal fall and ending applications a few weeks before

Corresponding author: E. Montesinos

E-mail: emonte@intea.udg.es

Accepted for publication 28 February 2000

Publication no. D-2000-0328-02R

(C) 2000 The American Phytopathological Society harvest. Therefore, a large number of fungicide applications is needed to maintain commercially acceptable levels of disease in affected orchards. These large amounts of fungicides delivered in pear orchards increase costs of production and may produce nontarget environmental and health effects in affected areas (16,35). Also, repeated use of some fungicides like procymidone has been associated with development of resistance to carboximides in $S$. vesicarium (4). However, some applications of fungicides may be unnecessary because environmental conditions are not always suitable for fruit or leaf infections by $S$. vesicarium (26).

An infection model, named BSPcast

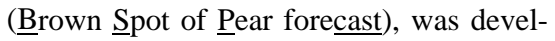
oped for prediction of infections of $S$. vesicarium on pear (26). The model quantifies the effect of daily wetness duration and temperature during wetness periods on brown spot disease severity on leaves and fruits. BSPcast was validated for disease prediction during 2 years in Catalunya (Spain) and Emilia-Romagna (Italy) in 40 field trials covering a wide range of wetness durations and temperatures $(21,26)$. Therefore, the model has potential for improving timing of fungicide applications in reduced spray programs, but it has not been evaluated specifically for this purpose in orchard trials.
The objective of this work was to evaluate the BSPcast model for scheduling fungicide applications in reduced-fungicide programs compared with the standard commercial schedule based on fixed sprays. The study was performed in plots and mesoscale trials in pear orchards of Spain and Italy naturally affected by brown spot.

\section{MATERIALS AND METHODS}

Brown spot forecasting system. The brown spot forecasting system (BSPcast) is based on an empirical model which has been previously described (26). The model determines when environmental conditions are favorable for infection of pear by $S$. vesicarium and for disease development. Daily wetness duration $(W)$ and mean air temperature during wetness periods $(T)$ are used to compute a daily disease severity $(S)$ according to the following equation:

$\log _{10}(S)=-1.70962+0.0289 T+0.04943 W+$ $0.00868 T W-0.002362 W^{2}-0.000238 T^{2} W$

Since the maximum daily disease severity predicted by the equation was 3.7942 , relative daily infection risk $(R)$ was calculated as:

$$
R=S / 3.7942
$$

Therefore, $R$ ranged from 0 to 1 . The 3 day cumulative daily infection risk (CR) was computed by totaling $R$ values for the past 3 days and was used as an action threshold for spraying fungicides in the field trials. $R$ and $\mathrm{CR}$ were calculated every $24 \mathrm{~h}$.

Weather parameters measurement. Environmental parameters were monitored with automatic weather stations. Trials performed in Spain were monitored with CR10 or CR10X dataloggers (Campbell Scientific Ltd., Leicester, UK) connected to combined temperature-relative humidity (model MP100 or HMP35AC), wetness (model 237), and rainfall (model ARG100) electronic sensors. Dataloggers of type WST1410 (MTX, Bologna, Italy) were used in trials performed in Italy. Wetness sensors provided data on surface wetness ranging from 0 (dry) to 100 (water film). Values above 50 were considered wet. Temperature, relative humidity, and wetness sensors were placed on trees at 1.5 to 
$1.8 \mathrm{~m}$ above the soil surface and in the middle of orchard plots. The rainfall sensors were placed at the end of a row of trees in a corner of the orchard plot. Temperature and relative humidity were measured every $10 \mathrm{~min}$ and wetness and rainfall every $20 \mathrm{~s}$. Mean temperature and relative humidity, duration of wetness, and total rainfall were recorded by the datalogger at hourly intervals. In previous studies $(21,24)$, it was observed that most wetness periods were due to dew that normally began at nightfall and ended at sunrise. Therefore, for each day, the 24-h period considered for calculations started at 8:00 h (GMT) of the previous day and finished at 8:00 h (GMT) of the current day. Every 24-h period, data were transferred to a PC using a modem connected to the phone line or taken directly to a portable computer, which calculated $R$ and CR.

Orchard trials. Eleven field trials were conducted in pear orchards in Catalunya (Spain) and Emilia-Romagna (Italy) during 1995, 1996, and 1997. The orchards were naturally infected by brown spot of pear. For identification throughout this report, number codes are assigned to each trial (Table 1). Experiments were performed in orchard plots of 80 to 100 trees or in mesoscale trials of 0.5 -ha size (about 600 trees). The orchard trials were done with pear cultivars Abate Fetel, Conference, and Passe Crassane, which are highly susceptible to the disease. Trials 1, 2, 3, 4, 5, 7, 9, and 10 correspond to plot level, and trials 6,8 , and 11 were performed at mesoscale level.

Fungicides used were thiram (Pomarsol Forte, $200 \mathrm{~g}$ a.i./hl), procymidone (Sumisclex, 60 to $75 \mathrm{~g}$ a.i./hl), and kresoximmethyl (Stroby, $10 \mathrm{~g}$ a.i./hl). Fungicides were applied in plot trials with an engineoperated portable sprayer (Stihl model SR400, Waiblingen, Germany) and in mesoscale trials with a 1,000-liter commercial sprayer. Spray volumes were calibrated to 1 liter per tree or 1,000 liters per ha. Thiram was assumed to provide 7 days of protection and procymidone and kresoxim-methyl 15 days, except when rainfall surpassed $20 \mathrm{~mm}$, in which case trees were sprayed again.
Fungicide treatments consisted of fixed or BSPcast-guided spray application schedules and nontreated controls. In the fixed spray schedule, fungicides were applied at 7-day (thiram) or 14-day (procymidone and kresoxim-methyl) intervals. A strategy to minimize selection of fungicide-resistant pathogens consisted of one thiram spray after three sprays of kresoxim-methyl. Treatments in the fixed spray schedule started after petal fall, usually between the last week of April and the third week of May. In guided spray schedules, the fungicides were applied when the selected CR action threshold $(0.4,0.5$, or 0.6$)$ was reached according to the BSPcast model. Treatments were applied within the 24-h period after reading datalogger output (8:00 GMT). Fungicide applications finished 2 weeks before harvest. Due to the varying length of the period from petal fall to harvest among pear cultivars, the total number of sprays in the standard schedule differed ( 24 for Passe Crassane, 16 to 18 for Conference, and 11 for Abate Fetel). Fruit of Abate Fetel and Conference were harvested in late August, and fruit of Passe Crassane were harvested in the second half of October.

In trials performed at the orchard plot level, treatments within each plot were four to five trees per treatment. Repetitions were separated from each other by two guard trees, and care was taken to avoid drift to adjacent treatments. In mesoscale trials, treatments were applied in a 0.5-ha orchard area, and data on disease were taken from three plots (repetitions) of 10 grouped trees selected within the treatment area.

Disease assessment. On fruit, disease incidence (\% of fruits) and severity (lesions per fruit) were assessed on 20 fruits per tree every 15 to 20 days starting after fruit set and ending at harvest. At harvest, all fruit were assessed.

Disease levels on leaves were determined only in trials $2,4,5,7,9$, and 10 , every 15 to 20 days. Measurements were performed on 10 leaves of four previously tagged shoots per tree located on both sides of the row. Disease severity per shoot was calculated according to a scale index based on approximate lesion numbers per leaf corresponding to 0 (none), 1 (1 to 5 lesions), 2 (6 to 25 lesions), and 3 (more than 25 lesions) according to the following formula:

$$
S=\frac{\sum_{n=1}^{L} I_{n}}{3 L}
$$

where $S$ is disease severity (relative index) from 0 to $1, I$ is the scale index of each leaf, 3 is the maximum level of severity measured per leaf, and $L$ is the number of leaves assessed per shoot. The mean disease incidence and severity on leaves for each tree were calculated from the values of each of the four shoots per tree and used in statistical analysis. Treatment efficacy was calculated as the relative percentage of disease reduction in treatments compared with the nontreated control.

Data analysis. Data of disease incidence and severity on fruits and leaves at harvest were analyzed using PC-SAS package (SAS System v.6.12, SAS Institute, Cary, NC). All data sets were tested for equality of variances (Bartlett test) and normality (Shapiro-Wilk test). In some cases, transformations were performed before analysis using arcsine $(x)$ or sqrt $(x / 2)$. The effect of treatments was determined by means of ANOVA for a randomized complete block

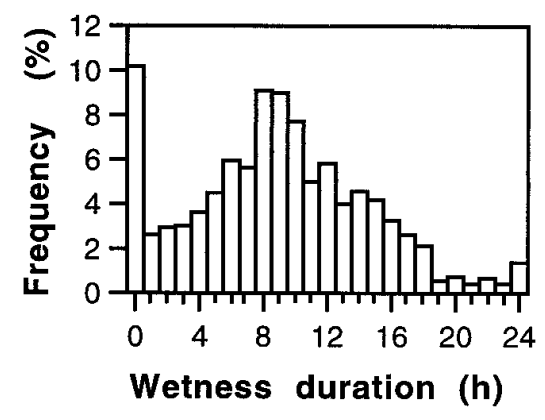

Fig. 1. Distribution of daily wetness duration during the 11 field trials performed in EmiliaRomagna (Italy) and Catalunya (Spain) for the evaluation of BSPcast model for scheduling fungicide sprays for control of brown spot of pear. Data correspond to 1,237 observations from May through October of 1995 to 1997.

Table 1. Trials performed for evaluation of BSPcast model in reduced fungicide programs for control of brown spot of pear

\begin{tabular}{llccccc}
\hline Trial & Year & Orchard location & Country & Pear cultivar & Trial size $^{\mathbf{z}}$ & Fungicide $^{\text {Plon }}$ \\
\hline 1 & 1995 & Altedo & Italy & Abate Fetel & Plot & Procymidone \\
2 & 1995 & Riudellots & Spain & Passe Crassane & Plot & Thiram \\
3 & 1996 & Altedo & Italy & Abate Fetel & Plot & Procymidone \\
4 & 1996 & Perello & Spain & Passe Crassane & Plot & Thiram \\
5 & 1996 & Riudellots & Spain & Passe Crassane & Plot & Thiram \\
6 & 1997 & Altedo & Italy & Conference & Mesoscale & Thiram \\
7 & 1997 & Estanyol & Spain & Conference & Plot & Thiram \\
8 & 1997 & Fontanilles & Spain & Conference & Mesoscale & Thiram \\
9 & 1997 & Perello-1 & Spain & Passe Crassane & Plot & Kresoxim-methyl/thiram \\
10 & 1997 & Perello-2 & Spain & Passe Crassane & Plot & Thiram \\
11 & 1997 & S. Martino & Italy & Abate Fetel & Mesoscale & Thiram \\
\hline
\end{tabular}

${ }^{\mathrm{z}}$ Field plot treatments were arranged in a completely randomized block design with four repetitions of five trees per repetition. Mesoscale trials consisted of 0.5 ha within the orchards. 
or completely randomized design using the GLM procedure and contrasts. Means comparisons were performed with Tukey's test. Linear regression was performed with REG procedure.

\section{RESULTS}

Dynamics of disease risk in relation to wetness duration and temperature of

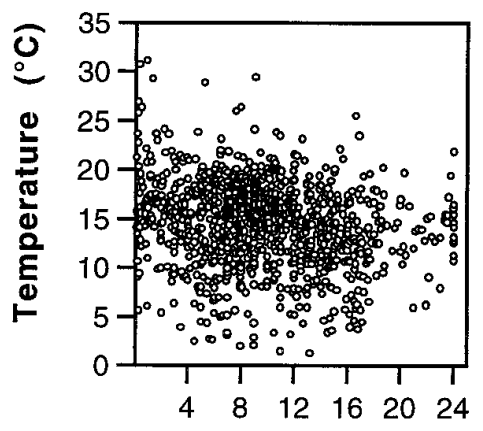

Wetness duration (h)

Fig. 2. Scatterplot of the mean air temperature of the wetness period and daily wetness duration for the 1,237 daily periods recorded during the 11 field trials performed for evaluation of the BSPcast model. Days without wetness are not represented. wetness periods. Daily wetness duration of the 1,237 daily periods recorded in all trials followed a bimodal frequency distribution. The distribution was characterized by $10 \%$ of cases having values lower than $0.5 \mathrm{~h}$ and the remaining $90 \%$ distributed normally. Most frequent wetness duration ranged from 8 to $10 \mathrm{~h}$, and values higher than $18 \mathrm{~h}$ represented only $5 \%$ of cases (Fig. 1).

The mean temperature of wetness periods ranged from 2 to $31^{\circ} \mathrm{C}$, and in $85 \%$ of cases was between 9 and $21^{\circ} \mathrm{C}$ (Fig. 2). A slight tendency $(P=0.0001)$ of lower temperature was observed when duration of wetness period increased.

The dynamics of meteorological parameters showed a direct relationship between days with rainfall and longest wetness (Fig. 3). Consequently, a high relationship was also observed between days with rainfall and $R$. However, some long wetness periods were due only to dew.

Generally, May and June were characterized by low mean temperatures during wetness periods, relatively constant daily duration of relative humidity higher than $90 \%$, and several rains. The first high value of $R$ (above 0.4 ) occurred during May or June and normally after days with rain. July was relatively dry with few rains. August and especially September and Oc- tober were relatively wet and were characterized by long daily wetness duration, frequent daily periods of high relative humidity, decreased temperatures of wetness periods, and frequent rains.

Disease progress in relation to infection risk and treatments. Patterns of disease progress in relation to infection risk and treatments are shown in Figure 4. The disease progress curve usually started after the first significant CR peak, and its progression was not continuous. Generally, changes in disease progress curve slope coincided with $\mathrm{CR}$ peaks above 0.6 . These can be observed for progress curves of disease severity on fruits in nontreated controls. On leaves, disease generally progressed faster than on fruits. Treatments effectively decreased disease progression on fruits but were less effective on leaves (trials 2, 4, and 7). Only in trials 5 and 9 did all treatments significantly decrease disease progression on leaves and fruits.

Disease control at harvest using fungicide spray schedules based on BSPcast system. Disease incidence on fruits at harvest in nontreated orchard plots ranged from 30.5 to $96.5 \%$, whereas in mesoscale trials (trials 6,8 , and 11) disease incidence ranged from 3.5 to $57.1 \%$ (Table 2). Also, disease incidence at harvest was significantly lower in fungicide treatments, either
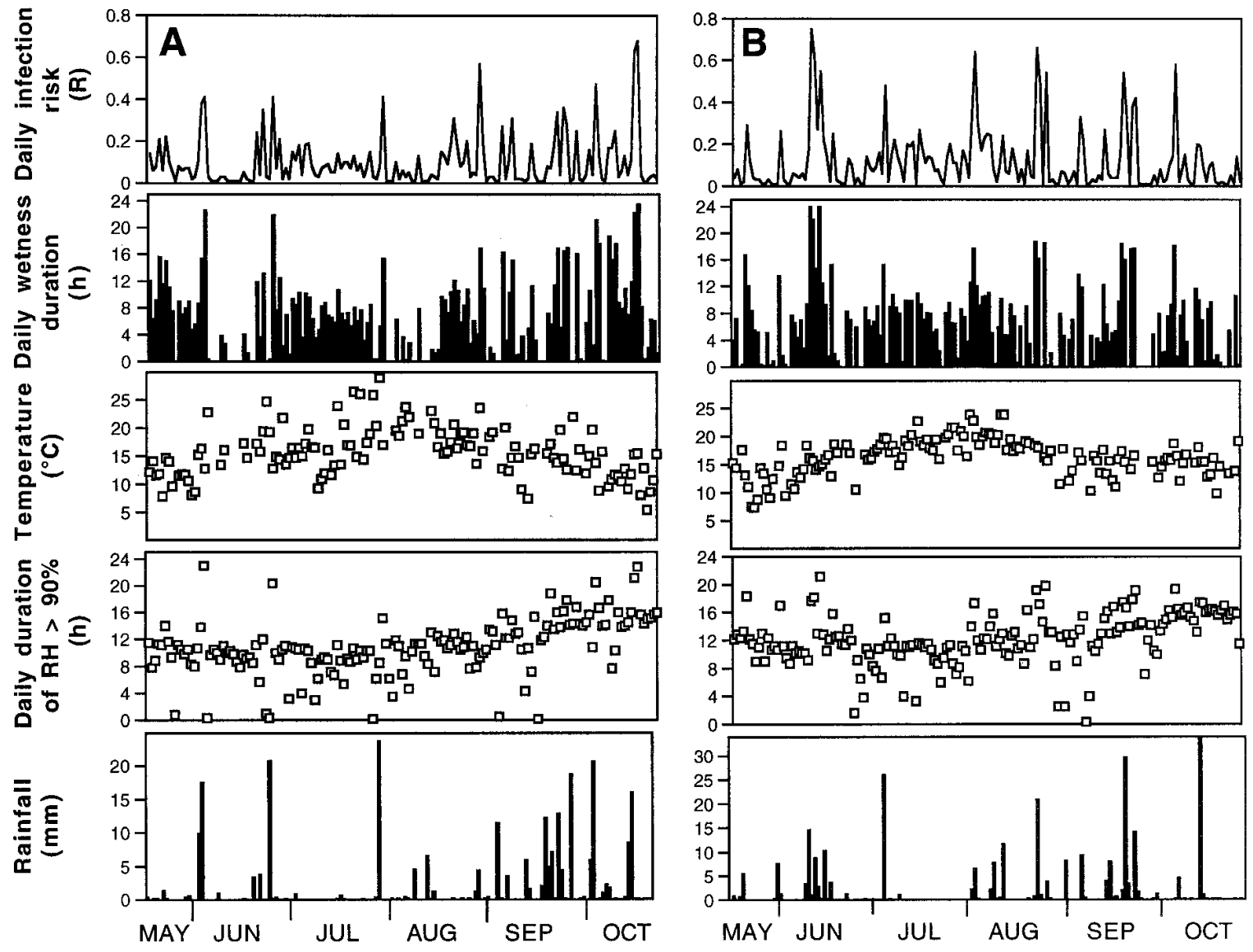

Fig. 3. Dynamics of daily infection risk (R), daily wetness duration, mean air temperature during the wetness period, duration of relative humidity above $90 \%$, and rainfall in trial 5 (A) and trial 2 (B). 
BSPcast-scheduled or fixed, than in nontreated controls $(P<0.05)$. Mean disease severity on fruits at harvest ranged from 0.5 to 5.5 lesions per fruit (Table 3 ). In all trials, disease severity was significantly higher $(P<0.05)$ in nontreated controls than in fungicide treatments.

Regardless of the fungicide used and of the spray schedule, the efficacy of fungicide treatments in disease reduction was high (70 to $94 \%$ ) in trials where disease incidence in untreated controls was moderate (30 to $60 \%$ ) (trials $1,2,3,6,8$, and 11 ). On the other hand, the efficacy was low (45 to $60 \%$ ) in trials where disease incidence in nontreated controls was high (65 to $96 \%$ ) (trials 4, 5, 7, 9, and 10).

Disease incidence observed in fruits sprayed according to a CR threshold of 0.4 was not significantly different from the fixed spray schedule (6 out of 7) in orchard plot level trials (Table 2). The savings in number of fungicide sprays in BSPcastguided schedules compared with the fixed spray schedule were 20 to $27 \%$ with kresoxim-methyl or procymidone and 20 to
$50 \%$ with thiram. In one case (trial 10) in which thiram was used, more disease was observed in the CR 0.4 schedule than in the fixed spray schedule, but still significantly less disease than in nontreated controls.

Disease incidence on fruits did not differ significantly from the fixed spray schedule in two out of five orchard plot trials sprayed according to CR threshold of 0.6. In trials 1 and 4, the savings in number of fungicide sprays were $48 \%$ for thiram and $73 \%$ for procymidone. In trials 2,5 , and 7 , disease incidence in plots sprayed according to the CR threshold of 0.6 was significantly higher than in the fixed spray schedule, but was significantly lower $(P<$ $0.05)$ than in nontreated controls.

In trials done at mesoscale level (trials 6 , 8 , and 11), disease incidence in treatments guided with BSPcast did not differ significantly from treatments done at fixed spray schedule (Table 2), and savings in number of sprays ranged between 20 and $40 \%$.

Considering all trials, disease reduction with the fixed spray schedule was similar to the BSPcast-guided schedule at CR 0.4 and 0.5 , but generally greater than CR 0.6. In treatments scheduled at action thresholds of CR 0.4 or 0.5 , savings accounted for $43 \%$ from 15 April to 15 June, $42 \%$ from 15 June to 15 August, and only 29\% from 15 August to 15 October, where the number of days with $\mathrm{CR}$ above 0.4 was high.

No statistically significant differences in disease severity on fruits were observed between fixed and BSPcast-scheduled fungicide treatments (Table 3).

Disease incidence on leaves at harvest in nontreated controls ranged from 94 to $98 \%$. Mean disease severity on leaves in nontreated controls was similar in all trials and ranged from 0.48 to 0.68 lesions per leaf (Table 4). Disease incidence and severity in leaves were not significantly different between the fixed spray schedule and the CR 0.4 BSPcast-schedule (Table 4). Only in trials 4 and 5 were differences not significant $(P>0.05)$ for disease incidence and severity between fixed and CR 0.6 .
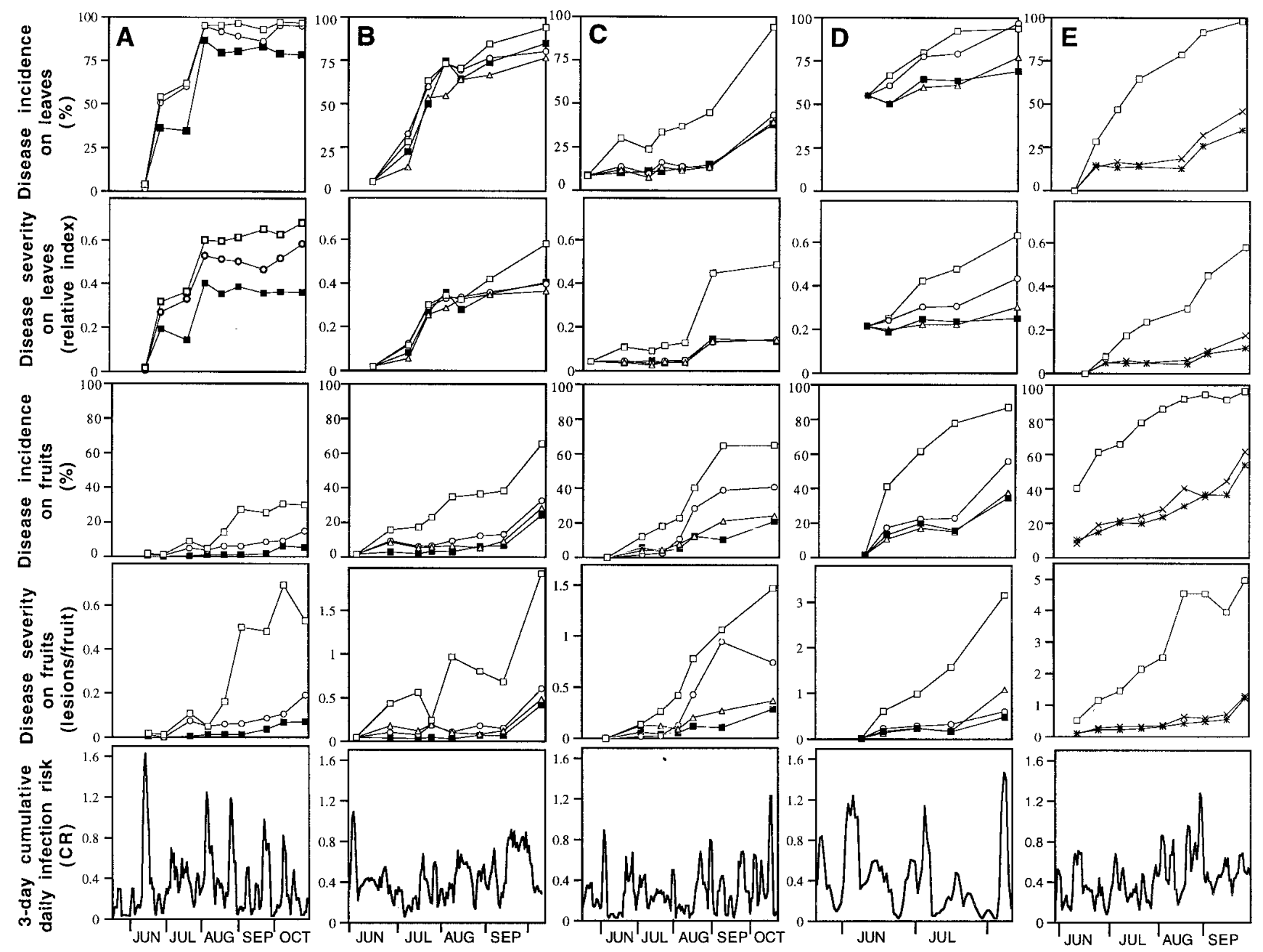

Fig. 4. Brown spot disease progress curves on leaves and fruits for nontreated controls $(\square)$, treated with thiram at fixed spray schedule ( $\square$ ), treated with thiram at BSPcast threshold $C R=0.4(\Delta)$, treated with thiram at BSPcast threshold $C R=0.6(\mathrm{O})$, treated with kresoxim-methyl plus thiram at fixed spray schedule (*), and treated with kresoxim-methyl plus thiram at BSPcast $\mathrm{CR}=0.4(\times)$, in relation to the dynamics of the 3-day cumulative daily infection risk (CR). Data correspond to trials $2(\mathbf{A}), 4(\mathbf{B}), 5(\mathbf{C}), 7$ (D), and 9 (E). Values of disease incidence and severity are the mean of four repetitions of four to five trees per repetition. 


\section{DISCUSSION}

Validation of warning systems as tools for reduced fungicide use is generally achieved by comparison of schedules based on guided sprays to fixed sprays and nontreated controls $(22,33)$. In the present study, we used this approach for BSPcast validation, and nontreated controls were performed to measure disease pressure, whereas the fixed spray schedule was used to assess the maximum disease control level achievable.

The BSPcast model uses direct measurement of wetness rather than estimates from rainfall, relative humidity, and temperature. The use of a single parameter indicating water availability for the fungal spores has the advantage of simplicity and is used in other forecasting systems such as FAST, a forecasting model for Alternaria solani on tomato (23). However, measuring wetness is more difficult than measuring temperature, relative humidity, and rainfall (34), because it is strongly dependent on the kind of sensor used $(10,11,18)$, its position $(7,17)$, and its orientation and location with respect to the vegetation (15).

The frequency distribution of duration of wetness periods observed during our work was in agreement with other reports for different crops $(1,7,13,19)$, particularly apple (32). Most wetness periods recorded during our trials were due to dew, but wetness due to rain was also important.

Table 3. Severity of brown spot on fruits (lesions per fruit) at harvest and number of fungicide treatments according to fixed and BSPcast guided fungicide spray application programs

\begin{tabular}{lcccc}
\hline & & \multicolumn{2}{c}{ BSPcast scheduled $^{\mathbf{x}}$} & \\
\cline { 3 - 4 } Trial & Fixed $^{\mathbf{w}}$ & $\mathbf{C R}=\mathbf{0 . 4}$ & $\mathbf{C R}=\mathbf{0 . 6}$ & Nontreated \\
\hline 2 & $0.1^{\mathrm{y}}$ & $\ldots$ & $0.2 \mathrm{~ns}^{\mathrm{z}}$ & 0.5 \\
4 & 0.4 & $0.5 \mathrm{~ns}$ & $0.6 \mathrm{~ns}$ & 1.9 \\
5 & 0.3 & $0.4 \mathrm{~ns}$ & $0.7 \mathrm{~ns}$ & 1.5 \\
7 & 0.5 & $0.6 \mathrm{~ns}$ & $1.1 \mathrm{~ns}$ & 3.2 \\
9 & 1.2 & $1.2 \mathrm{~ns}$ & $\ldots$ & 5.5 \\
10 & 1.2 & $2.1 \mathrm{~ns}$ & $\ldots$ & 5.5 \\
\hline
\end{tabular}

${ }^{\mathrm{w}}$ Commercial fungicide spray schedule applied at a fixed interval of 7 or 14 days depending on fungicide.

${ }^{x}$ Fungicide sprays scheduled according to the BSPcast model using 3-day cumulative daily infection risk (CR) thresholds.

y Mean number of lesions per fruit.

${ }^{\mathrm{z}}$ Significance according to ANOVA with contrasts comparing fixed and BSPcast scheduled fungicide sprays. ns, not significant $(P>0.05)$.

Table 2. Incidence of brown spot on fruits at harvest in relation to timing and number of fungicide applications for each trial according to the treatment schedule used

\begin{tabular}{|c|c|c|c|c|c|c|c|c|c|c|c|c|c|c|c|c|c|c|c|c|c|c|c|c|c|c|}
\hline \multirow[b]{2}{*}{ Trial } & \multirow{2}{*}{$\begin{array}{l}\operatorname{Trtmt}^{\mathrm{x}} \\
\text { schedule }\end{array}$} & \multicolumn{23}{|c|}{ Weeks after April 21} & \multirow{2}{*}{$\begin{array}{c}\text { no. of } \\
\text { sprays }\end{array}$} & \multirow{2}{*}{$\begin{array}{l}\text { Fruit disease } \\
\text { incidence at } \\
\text { harvest }(\%)\end{array}$} \\
\hline & & $\overline{0}$ & 1 & 2 & 3 & 4 & 5 & 6 & 7 & 8 & 9 & 10 & 11 & 12 & 13 & 14 & 15 & 16 & 17 & 18 & 19 & 20 & 21 & 22 & & \\
\hline \multirow[t]{4}{*}{$\overline{1}$} & Nontreated & & $-\mathrm{y}$ & - & - & - & - & - & - & - & - & & - & - & & - & - & & & & & & & & --- & 52.5 \\
\hline & Fixed & $\mathrm{X}$ & & $\mathrm{X}$ & & $\mathrm{X}$ & $\mathrm{X}$ & $X$ & & $X$ & $\mathrm{X}$ & & $\mathrm{X}$ & $\mathrm{X}$ & & $\mathrm{X}$ & $\mathrm{X}$ & & & & & & & & 11 & 3.1 \\
\hline & CR 0.4 & $\mathrm{X}$ & & $\mathrm{X}$ & & - & $\mathrm{X}$ & $\mathrm{X}$ & & - & $\mathrm{X}$ & & $\mathrm{X}$ & $\mathrm{X}$ & & - & $\mathrm{X}$ & & & & & & & & 8 & $5.4 \mathrm{~ns}^{2}$ \\
\hline & CR 0.6 & $\mathrm{X}$ & & $\mathrm{X}$ & & - & - & - & & - & - & & $\mathrm{X}$ & - & & - & - & & & & & & & & 3 & $4.7 \mathrm{~ns}$ \\
\hline \multirow[t]{3}{*}{2} & Nontreated & & & & - & - & - & - & - & - & - & - & - & - & - & - & - & - & - & - & - & - & - & - & -- & 30.5 \\
\hline & Fixed & & & & $\mathrm{X}$ & $\mathrm{X}$ & $\mathrm{X}$ & * & $\mathrm{X}$ & $\mathrm{X}$ & $\mathrm{X}$ & $\mathrm{X}$ & $\mathrm{X}$ & $\mathrm{X}$ & $\mathrm{X}$ & $\mathrm{X}$ & $\mathrm{X}$ & $\mathrm{X}$ & $\mathrm{X}$ & $\mathrm{X}$ & $*$ & $\mathrm{X}$ & $\mathrm{X}$ & * & 23 & 5.5 \\
\hline & CR 0.6 & & & & $\mathrm{X}$ & - & - & $\mathrm{X}$ & - & - & $X$ & - & - & - & $\mathrm{X}$ & - & $X$ & - & - & - & $\mathrm{X}$ & - & $X$ & - & 7 & $15.2 \mathrm{~s}(0.0011)$ \\
\hline \multirow[t]{3}{*}{3} & Nontreated & $1-$ & - & - & & - & - & & - & - & & - & & - & - & - & & - & & & & & & & -- & 41.2 \\
\hline & Fixed & $\mathrm{X}$ & $*$ & $\mathrm{X}$ & & $\mathrm{X}$ & $\mathrm{X}$ & & $\mathrm{X}$ & $\mathrm{X}$ & & $\mathrm{X}$ & & $\mathrm{X}$ & $\mathrm{X}$ & $\mathrm{X}$ & & $\mathrm{X}$ & & & & & & & 13 & 7.4 \\
\hline & CR 0.4 & $\mathrm{X}$ & - & - & & - & - & & - & $\mathrm{X}$ & & - & & - & - & $\mathrm{X}$ & & - & & & & & & & 3 & $11.3 \mathrm{~ns}$ \\
\hline \multirow[t]{4}{*}{4} & Nontreated & & & & - & - & - & - & - & - & - & - & - & - & - & - & - & - & - & - & - & - & - & & -- & 65.7 \\
\hline & Fixed & & & & $\mathrm{X}$ & $\mathrm{X}$ & $\mathrm{X}$ & $\mathrm{X}$ & $\mathrm{X}$ & $\mathrm{X}$ & $\mathrm{X}$ & $\mathrm{X}$ & $\mathrm{X}$ & $*$ & $\mathrm{X}$ & $\mathrm{X}$ & $\mathrm{X}$ & $\mathrm{X}$ & $\mathrm{X}$ & $\mathrm{X}$ & $* *$ & $*$ & $\mathrm{X}$ & & 23 & 24.6 \\
\hline & CR 0.4 & & & & - & $X$ & $X$ & $X$ & $X$ & $X$ & - & - & $\mathrm{X}$ & $X$ & - & $\mathrm{X}$ & $X$ & $\mathrm{X}$ & $\mathrm{X}$ & - & $* *$ & $*$ & $X$ & & 17 & $28.6 \mathrm{~ns}$ \\
\hline & CR 0.6 & & & & - & $\mathrm{X}$ & $\mathrm{X}$ & - & - & $X$ & - & - & $\mathrm{X}$ & $\mathrm{X}$ & - & $\mathrm{X}$ & $\mathrm{X}$ & - & $\mathrm{X}$ & - & $*$ & $\mathrm{X}$ & $\mathrm{X}$ & & 12 & $32.9 \mathrm{~ns}$ \\
\hline \multirow[t]{4}{*}{5} & Nontreated & & & - & - & - & - & - & - & - & - & - & - & - & - & - & - & - & - & - & - & - & - & - & -- & 65.1 \\
\hline & Fixed & & & $\mathrm{X}$ & $\mathrm{X}$ & $\mathrm{X}$ & $\mathrm{X}$ & $X$ & $X$ & $X$ & $X$ & $\mathrm{X}$ & $\mathrm{X}$ & $*$ & $X$ & $\mathrm{X}$ & $X$ & $\mathrm{X}$ & $\mathrm{X}$ & $X$ & $*$ & $X$ & $*$ & $X$ & 24 & 21.1 \\
\hline & CR 0.4 & & & - & - & - & $X$ & - & $X$ & $X$ & $X$ & - & - & $X$ & - & - & $X$ & $\mathrm{X}$ & - & $X$ & $\mathrm{X}$ & $X$ & $\mathrm{X}$ & $X$ & 12 & $24.2 \mathrm{~ns}$ \\
\hline & CR 0.6 & & & - & - & - & $\mathrm{X}$ & - & - & $X$ & - & - & $\mathrm{X}$ & $X$ & - & - & $X$ & - & * & - & - & - & - & - & 7 & $40.9 \mathrm{~s}(0.0083)$ \\
\hline \multirow[t]{3}{*}{6} & Nontreated & & - & - & - & - & - & - & - & - & - & - & - & - & - & - & - & & & & & & & & -- & 10.8 \\
\hline & Fixed & & $\mathrm{X}$ & $\mathrm{X}$ & $\mathrm{X}$ & $\mathrm{X}$ & $\mathrm{X}$ & $\mathrm{X}$ & $*$ & $\mathrm{X}$ & $\mathrm{X}$ & $\mathrm{X}$ & $\mathrm{X}$ & $*$ & $\mathrm{X}$ & $\mathrm{X}$ & $*$ & & & & & & & & 18 & 3.9 \\
\hline & CR 0.5 & & - & $\mathrm{X}$ & - & - & $\mathrm{X}$ & $\mathrm{X}$ & $*$ & $\mathrm{X}$ & $\mathrm{X}$ & $\mathrm{X}$ & $\mathrm{X}$ & $\mathrm{X}$ & $\mathrm{X}$ & - & $*$ & & & & & & & & 13 & $5.0 \mathrm{~ns}$ \\
\hline \multirow[t]{4}{*}{7} & Nontreated & & & - & - & - & - & - & - & - & - & - & - & - & - & & & & & & & & & & -- & 87.0 \\
\hline & Fixed & & & $\mathrm{X}$ & $\mathrm{X}$ & $*$ & $*$ & $X$ & $\mathrm{X}$ & $* *$ & $\mathrm{X}$ & $\mathrm{X}$ & $\mathrm{X}$ & $\mathrm{X}$ & $X$ & & & & & & & & & & 16 & 34.7 \\
\hline & CR 0.4 & & & $\mathrm{X}$ & $\mathrm{X}$ & $\mathrm{X}$ & $*$ & $\mathrm{X}$ & $\mathrm{X}$ & $*$ & $\mathrm{X}$ & - & $\mathrm{X}$ & - & - & & & & & & & & & & 11 & $37.7 \mathrm{~ns}$ \\
\hline & CR 0.6 & & & $\mathrm{X}$ & - & $\mathrm{X}$ & $*$ & $\mathrm{X}$ & - & $*$ & - & - & - & - & - & & & & & & & & & & 7 & $56.0 \mathrm{~s}(0.0026)$ \\
\hline \multirow[t]{3}{*}{8} & Nontreated & & & & & - & - & - & - & - & - & - & - & - & & & & & & & & & & & -- & 3.5 \\
\hline & Fixed & & & & & $\mathrm{X}$ & $\mathrm{X}$ & $\mathrm{X}$ & $*$ & $\mathrm{X}$ & $\mathrm{X}$ & $*$ & $\mathrm{X}$ & $\mathrm{X}$ & & & & & & & & & & & 11 & 1.3 \\
\hline & CR 0.4 & & & & & $\mathrm{X}$ & - & - & $*$ & - & $\mathrm{X}$ & * & $\mathrm{X}$ & - & & & & & & & & & & & 7 & $2.8 \mathrm{~ns}$ \\
\hline \multirow[t]{3}{*}{9} & Nontreated & & & & & - & & - & & - & & - & & - & - & & - & & - & & - & & & & -- & 96.4 \\
\hline & Fixed & & & & & $\mathrm{X}$ & & $X$ & & $X$ & & $\mathrm{X}$ & & $*$ & $X$ & & $X$ & & $\mathrm{X}$ & & $\mathrm{X}$ & & & & 10 & 52.7 \\
\hline & CR 0.4 & & & & & $\mathrm{X}$ & & $\mathrm{X}$ & & $\mathrm{X}$ & & $\mathrm{X}$ & & $\mathrm{X}$ & - & & $\mathrm{X}$ & & $\mathrm{X}$ & & $\mathrm{X}$ & & & & 8 & $59.2 \mathrm{~ns}$ \\
\hline \multirow[t]{3}{*}{10} & Nontreated & & & & & - & - & - & - & - & - & - & - & - & - & - & - & - & - & - & - & & & & -- & 96.5 \\
\hline & Fixed & & & & & $\mathrm{X}$ & $*$ & $\mathrm{X}$ & $\mathrm{X}$ & $* *$ & $\mathrm{X}$ & $\mathrm{X}$ & $\mathrm{X}$ & $\mathrm{X}$ & $\mathrm{X}$ & $*$ & $\mathrm{X}$ & $\mathrm{X}$ & $\mathrm{X}$ & $\mathrm{X}$ & $\mathrm{X}$ & & & & 20 & 53.2 \\
\hline & CR 0.4 & & & & & - & $*$ & - & $\mathrm{X}$ & $*$ & $\mathrm{X}$ & - & $\mathrm{X}$ & $\mathrm{X}$ & $X$ & - & $\mathrm{X}$ & $\mathrm{X}$ & $\mathrm{X}$ & $\mathrm{X}$ & $\mathrm{X}$ & & & & 14 & $73.7 \mathrm{~s}(0.0002)$ \\
\hline \multirow[t]{3}{*}{11} & Nontreated & & - & - & - & - & - & - & - & - & - & - & - & - & - & - & - & & & & & & & & -- & 57.1 \\
\hline & Fixed & & $\mathrm{X}$ & $\mathrm{X}$ & $\mathrm{X}$ & $\mathrm{X}$ & $\mathrm{X}$ & $X$ & $X$ & $X$ & $X$ & $\mathrm{X}$ & $\mathrm{X}$ & $\mathrm{X}$ & $\mathrm{X}$ & $\mathrm{X}$ & $\mathrm{X}$ & & & & & & & & 15 & 7.0 \\
\hline & CR 0.5 & & $\mathrm{X}$ & $\mathrm{X}$ & - & $\mathrm{X}$ & $\mathrm{X}$ & $\mathrm{X}$ & $\mathrm{X}$ & $\mathrm{X}$ & $\mathrm{X}$ & - & - & $\mathrm{X}$ & $\mathrm{X}$ & $\mathrm{X}$ & $\mathrm{X}$ & & & & & & & & 12 & $12.5 \mathrm{~ns}$ \\
\hline
\end{tabular}

${ }^{\mathrm{x}}$ Fixed, commercial fungicide spray schedule applied at a fixed interval of 7 or 14 days depending on fungicide; CR 0.4 , CR 0.5 , or CR 0.6, fungicide sprays according to the BSPcast model predictions using 3-day cumulative daily infection risk (CR) action thresholds of 0.4, 0.5, or 0.6.

y X, sprayed once during this week; -, not sprayed; *, sprayed twice; **, sprayed three times after more than 20 mm rainfall following the fungicide application.

${ }^{\mathrm{z}}$ Significance according to ANOVA with contrasts comparing fixed and BSPcast scheduled fungicide sprays; ns, not significant $(P>0.05)$; s, significant $(P<0.05)$. The $P$ value for which $F$ was significant is shown in parentheses. 
Duration of wetness and temperature of wetness periods observed most days during the course of the present study were not favorable to infections by $S$. vesicarium. This is supported by previous studies in which optimal conditions for leaf and fruit infection by $S$. vesicarium on pear were found above 10 to $12 \mathrm{~h}$ and temperatures of the wetness periods were higher than $15^{\circ} \mathrm{C}(26)$. Also, high relative humidity has little influence on spore germination of $S$. vesicarium, since this only occurs when values are high enough for dew formation $(21,27)$.

BSPcast predicted different levels of infection through the growing season of pear. The distribution of infection risk through the growing season followed a pattern characterized by two high-risk periods separated by a low-risk period. This pattern was in agreement with the pattern of progress of disease incidence on fruits and leaves at harvest on trees left unprotected by fungicides for 4-week periods distributed within the growing season $(26,27)$. Overall, disease risk increased until August-September. Another interesting aspect of BSPcast predictions is that the first significant daily risk peak above CR 0.4 predicted by the model coincided with the onset of the disease progression curves. Therefore, this peak can be used to properly position the start of fungicide applications in BSPcast-guided schedules. This is particularly important because a reduction of disease levels or delay in disease initiation may influence considerably disease levels at the end of epidemics (37).

Thiram, kresoxim-methyl, and procymidone applied in a full-season protectant program provided efficient brown spot disease control when the level of disease pressure was moderate, but the efficacy of control was low under high disease pressure. None of the fungicides tested, despite intensive applications, had high control efficacy of brown spot when disease pressure was high, and this is in agreement with previous reports $(3,5,29-31,36)$.

The BSPcast model performed well at CR 0.4 or 0.5 in reduced fungicide spray programs, both in trials done at mesoscale level under commercial production conditions and in those performed at plot level.
Overall, the savings in number of fungicide sprays applied using BSPcast compared with the fixed spray schedule were 20 to $70 \%$ with kresoxim-methyl or procymidone (15-day protection period) and ranged from 20 to $50 \%$ with thiram (7-day protection period). Only in one trial was disease incidence significantly higher using BSPcast than with the fixed spray schedule, and this occurred under conditions of high disease pressure and early disease initiation. Fungicide spray savings obtained with BSPcast were of the same order as those reported with similar models $(6,12,14,20,28)$, including FAST, for management of brown spot of pear (27).

The action threshold value used for timing fungicide sprays with BSPcast is very critical above CR 0.4 to 0.5 , since disease control levels obtained with a threshold of 0.6 were not commercially acceptable. This was because in most of our trials, disease pressure was moderate to high, and under such conditions efficacy of fungicide treatments decreased considerably and a more restrictive threshold was necessary for disease control. Better performance of CR 0.6 with the advantage of more savings is expected under low disease pressure.

The tolerance threshold of incidence of brown spot on pear fruit at market level is close to zero, and for this reason, we used incidence as the main parameter to assess model performance under commercial conditions. However, disease severity is also important in evaluating a disease management program, since reductions in disease severity on leaves and fruits reduce inoculum of the pathogen for the current and next growing seasons. When disease pressure in the orchard is high, reduced fungicide spray programs based on BSPcast may not be sufficient to decrease fungal inoculum on leaves, and a stronger management strategy should be adopted. One such strategy introduces less restrictive action thresholds as disease pressure decreases. The proposed system starts with a fixed spray schedule during the first year after a severe epidemic and moves to a guided strategy using BSPcast during subsequent years. Then, BSPcast can be used with restrictive action thresholds of 0.4 to
0.5 and progressively approach a maintenance CR of 0.6 for subsequent years. Also, the fact that disease risk increases in late summer may allow growers to start the season with a less restrictive $\mathrm{CR}$ action threshold of 0.6 and decrease progressively to 0.4 as harvest time approaches.

The results obtained during 3 years of study in 11 trials performed in two different climatic regions in Spain and Italy with three pear cultivars and three fungicides showed consistently that the BSPcast model is a useful tool for rational management of brown spot of pear. The use of BSPcast with CR action thresholds of 0.4 or 0.5 reduced the number of fungicide sprays and maintained the same levels of efficacy of control as the commercial fixed-spray schedule. Model implementation in warning stations will require additional data processing of the current CR output to account for effects of spore inoculum levels, phenological stage, and pear cultivar susceptibility $(21,26,27)$. Brown spot warning system software based on weather, pathogen, and host parameters, which provides disease risk and action threshold values to advise fungicide application programs, is under construction.

\section{ACKNOWLEDGMENTS}

This research was supported by grants from Comisión Interministerial de Ciencia y Tecnología, Instituto Nacional de Investigación y Tecnología Agraria y Alimentaria, Subdirección General de Cooperación Internacional of Spain, and Comissionat per a Universitats i Recerca of the Generalitat de Catalunya. We thank E. Badosa, C. Moragrega, and J. Pereda for helpful assistance.

\section{LITERATURE CITED}

1. Barthakur, N. N. 1985. A comparative study of radiometric and electronic leaf wetness sensors. Agric. For. Meteorol. 36:83-90.

2. Blancard, D., Allard, E., and Brest, P. 1989. La Stemphyliose du poirier ou "macules brunes". Phytoma 406:37-38.

3. Brunelli, A., Di Marco, G., Contarelli, G., and Ponti, I. 1984. Prove di lotta contro la maculatura bruna delle pere. ATTI Giornate Fitopatol. I:203-212.

4. Brunelli, A., Gherardi, I., and Adani, N. 1997. Ridotta sensibilità di Stemphylium vesicarium, agente della maculatura bruna del pero, ai fungicidi dicarbossimidici. Inform. Fitopatol. 9:44-48.

5. Brunelli, A., Rovesti, L., Di Marco, S., and Ponti, I. 1986. Attivita di diversi fungicidi contro la maculatura bruno del pero. Frutti-

Table 4. Incidence and severity of brown spot on leaves at harvest according to fixed and BSPcast guided fungicide spray application programs

\begin{tabular}{|c|c|c|c|c|c|c|c|c|}
\hline \multirow[b]{2}{*}{ Trial } & \multicolumn{4}{|c|}{ Incidence (\%) } & \multicolumn{4}{|c|}{ Severity (relative index) } \\
\hline & Fixed $^{x}$ & $\begin{array}{l}\text { BSPcast }^{y} \\
\mathrm{CR}=0.4\end{array}$ & $\begin{array}{l}\text { BSPcast } \\
\mathrm{CR}=0.6\end{array}$ & Nontreated & Fixed & $\begin{array}{l}\text { BSPcast } \\
\text { CR }=0.4\end{array}$ & $\begin{array}{l}\text { BSPcast } \\
\mathrm{CR}=0.6\end{array}$ & Nontreated \\
\hline 2 & $78.7 b^{z}$ & $\ldots$ & $95.1 \mathrm{a}$ & $97.0 \mathrm{a}$ & $0.36 \mathrm{C}$ & $\ldots$ & $0.58 \mathrm{~B}$ & $0.68 \mathrm{~A}$ \\
\hline 4 & $38.2 \mathrm{~b}$ & $39.7 \mathrm{~b}$ & $43.0 \mathrm{~b}$ & $94.0 \mathrm{a}$ & $0.14 \mathrm{~B}$ & $0.14 \mathrm{BC}$ & $0.14 \mathrm{~B}$ & $0.48 \mathrm{~A}$ \\
\hline 5 & $85.0 \mathrm{ab}$ & $76.9 \mathrm{~b}$ & $80.6 \mathrm{ab}$ & $94.0 \mathrm{a}$ & $0.40 \mathrm{AB}$ & $0.36 \mathrm{~B}$ & $0.40 \mathrm{AB}$ & $0.58 \mathrm{~A}$ \\
\hline 7 & $69.3 \mathrm{~b}$ & $77.3 \mathrm{ab}$ & $97.0 \mathrm{a}$ & $94.0 \mathrm{a}$ & $0.25 \mathrm{C}$ & $0.30 \mathrm{BC}$ & $0.43 \mathrm{~B}$ & $0.63 \mathrm{~A}$ \\
\hline 9 & $34.8 \mathrm{~b}$ & $46.0 \mathrm{~b}$ & $\ldots$ & $98.0 \mathrm{a}$ & $0.12 \mathrm{~B}$ & $0.17 \mathrm{~B}$ & $\ldots$ & $0.58 \mathrm{~A}$ \\
\hline 10 & $41.1 \mathrm{~b}$ & $52.5 \mathrm{~b}$ & $\ldots$ & $98.0 \mathrm{a}$ & $0.14 \mathrm{~B}$ & $0.18 \mathrm{~B}$ & $\ldots$ & $0.58 \mathrm{~A}$ \\
\hline
\end{tabular}

${ }^{\mathrm{x}}$ Commercial fungicide spray schedule applied at a fixed interval of 7 or 14 days depending on fungicide.

${ }^{\mathrm{y}}$ Fungicide sprays scheduled according to the BSPcast model using 3-day cumulative daily infection risk (CR) thresholds.

${ }^{\mathrm{z}}$ Mean incidence or severity values within a row followed by the same letter are not significantly different $(P=0.05)$ according to Tukey's means separation test. Means comparisons for incidence are in lowercase and for severity are in capitals. 
coltura 1:51-54.

6. Byrne, J. M., Hausbeck, M. K., and Latin, R. X. 1997. Efficacy and economics of management strategies to control anthracnose fruit rot in processing tomatoes in the Midwest. Plant Dis. 81:1167-1172

7. Caprara, C., and Veronesi, G. 1992. La misura dei parametri meteoclimatici in fitoiatria: la bagnatura fogliare. Inform. Fitopatol. 4:29-32.

8. Cavanni, P., Bugiani, R., and Govoni, P. 1992. Alternaria alternata, dal saprofitismo alla specializzazione patogenetica: il ruolo chiave delle tossine ospite-specifiche. Inform. Fitopatol. 6:33-40.

9. Cavanni, P., and Ponti, I. 1994. Maculatura bruna del pero: una micopatia sempre d'attualità. Riv. Fruticultura 12:37-42.

10. Egger, E., and Marinelli, E. 1995. Confronto tra diversi sensori ed un metodo per la stima della bagnatura fogliare. Inform. Fitopatol. 11:48-54.

11. Egger, E., Marinelli, E., and D'arcangelo, M. 1996. Influenza di diversi metodi per la stima della bagnatura fogliare sulla previsione degli attachi di peronospora e muffa grigia su vite. Inform. Fitopatol. 3:57-61.

12. Ellis, M. A., Madden, L. V., and Wilson, L. L. 1984. Evaluation of an electronic apple scab predictor for scheduling fungicides with curative activity. Plant Dis. 68:10551057.

13. Gillespie, T. J., and Kidd, G. E. 1978. Sensing duration of leaf moisture retention using electrical impedance grids. Can. J. Plant. Sci. 58:179-187.

14. Gleason, M. L., MacNab, A. A., Pitblado, R. E., Ricker, M. D., East, D. A., and Latin, R. X. 1995. Disease-warning systems for processing tomatoes in eastern North America: Are we there yet? Plant Dis. 79:113121.

15. Gozzini, B., Orlandini, S., and Seghi, L. 1996. Influenza della vegetazione e dell'orientamento del sensore sulla rilevazione della bagnatura fogliare. Inform. Fitopatol. 4:55-58

16. Gullino, M. L., and Kuijpers, L. A. M. 1994.
Social and political implications of managing plant diseases with restricted fungicides in Europe. Annu. Rev. Phytopathol. 32:559-579.

17. Huber, L., and Gillispie, T. J. 1992. Modeling leaf wetness in relation to plant disease epidemiology. Annu. Rev. Phytopathol. 30:553577.

18. Huber, L., and Wehrlen, J. M. 1988. La durée d'humectation en protection des plantes: mesure et modélisation. Déf. Vég. 252:3-11.

19. Jones, A. L., Lillevik, S. L., Fisher, P. D., and Stebbins, T. C. 1980. A microcomputer-based instrument to predict primary apple scab infection periods. Plant Dis. 64:69-72.

20. Keinath, A. P., DuBose, V. B., and Rathwell, P. J. 1996. Efficacy and economics of three fungicide application schedules for early blight control and yield of fresh-market tomato. Plant Dis. 80:1277-1282.

21. Llorente, I. 1997. Development of an infection risk forecast system for Stemphylium vesicarium. Evaluation, validation and implementation in experimental plots of pear commercial orchards. Ph.D. thesis. University of Girona, Girona, Spain.

22. Madden, L. V., and Ellis, M. A. 1988. How to develop plant disease forecasters. Pages 191208 in: Experimental Techniques in Plant Disease Epidemiology. J. Kranz and J. Rotem, eds. Springer-Verlag, New York.

23. Madden, L. V., Pennypacker, S. P., and MacNab, A. A. 1978. FAST, a forecast system for Alternaria solani on tomato. Phytopathology 68:1354-1358.

24. Montesinos, E., Llorente, I., Moragrega, C., Bonaterra, A., Cervantes, J., and Vilardell, P. 1996. Desarrollo y evaluación a escala productiva de un sistema de control racional de la estemfiliosis (Stemphylium vesicarium) del peral. Fruticultura Profesional 78:96-104

25. Montesinos, E., Moragrega, C., Llorente, I., and Vilardell, P. 1995. Susceptibility of selected European pear cultivars to infection by Stemphylium vesicarium and influence of leaf and fruit age. Plant Dis. 79:471-473.

26. Montesinos, E., Moragrega, C., Llorente, I., Vilardell, P., Bonaterra, A., Ponti, I., Bugiani,
R., Cavanni, P., and Brunelli, A. 1995. Development and evaluation of an infection mode for Stemphylium vesicarium on pear based on temperature and wetness duration. Phytopathology 85:586-592.

27. Montesinos, E., and Vilardell, P. 1992 Evaluation of FAST as a forecasting system for scheduling fungicide sprays for control of Stemphylium vesicarium on pear. Plant Dis. 76:1221-1226.

28. Pennypacker, S. P., Madden, L. V., and MacNab, A. A. 1983. Validation of an early blight forecasting system for tomatoes. Plant Dis. 67:287-289.

29. Ponti, I., Brunelli, A., Tosi, C., Basaglia, M Bevilacqua, T., Emiliani, G., Cont, C., and Viccinelli, R. 1993. Verifica dell'attività di diversi preparati contro la maculatura bruna del pero. Inform. Fitopatol. 5:45-52.

30. Ponti, I., Brunelli, A., Tosi, C., Cavallini, G., and Mazzinni, F. 1996. Aggiornamenti sull'attivita dei fungicidi contro la maculatura bruna del pero. ATTI Giornate Fitopatol. 2:165-172.

31. Ponti, I., Cavanni, P., and Brunelli, A. 1982. "Maculatura bruna" delle pere: eziologia e difesa. Inform. Fitopatol. 3:35-40.

32. Seem, R. C., Rubin, G., and Becker, C. M. 1988. Duration of leaf wetting and drying periods in orchards. (Abstr.) Phytopathology 78:1571.

33. Shtienberg, D., and Elad, Y. 1997. Incorporation of weather forecasting in integrated biological-chemical management of Botrytis cinerea. Phytopathology 87:332-340.

34. Sutton, J. C., Gillespie, T. J., and Hildebrand, P. D. 1984. Monitoring weather factors in relation to plant disease. Plant Dis. 68:78-84.

35. Sutton, T. B. 1996. Changing options for the control of deciduous fruit tree diseases. Annu. Rev. Phytopathol. 34:527-547.

36. Vilardell, P. 1988. Stemphylium vesicarium en plantaciones de peral. Fruticultura Profesional 18:51-55.

37. Zadoks, J. C., and Schein, R. D. 1979. Epidemiology and Plant Disease Management. Oxford University Press, Oxford. 